\title{
Decomposition of Free Chlorine with Tertiary Ammonium
}

\author{
Hajime Katano, ${ }^{* \dagger}$ Kohei Uematsu, $*$ Hirosuke TatsumI,** and Toshihide TsukatanI $* * *$ \\ *Department of Bioscience, Fukui Prefectural University, Eiheiji, Fukui 910-1195, Japan \\ **International Young Researchers Empowerment Center, Shinshu University, Matsumoto, \\ Nagano 390-8621, Japan \\ ***Research and Development Division, Nicca Chemical, Co. Ltd., Bunkyo, Fukui 910-8670, Japan
}

\begin{abstract}
The reaction of free chlorine with tertiary ammonium or amine compounds in aqueous solution was studied by the amperometry at a rotating Pt-disk electrode. The amperometric method can be applied to follow the concentration of free chlorine $\left(c_{\mathrm{Cl}}\right)$ even in the presence of chloramine species. By addition of mono- and dibutylammonium to the solution containing free chlorine, the step-like decrease in $c_{\mathrm{Cl}}$ was observed, indicating the rapid formation of the stable chloramine species. By addition of tributylammonium, the $c_{\mathrm{Cl}}$ was decreased exponentially to nearly zero even if the free chlorine was present initially in excess. The $c_{\mathrm{Cl}} t$ curves can be explained by tributylammonium-species-catalyzed decomposition of free chlorine to chloride ion. The catalytic decomposition was observed also with the tertiary-ammonium-based anion-exchange resins. Furthermore, the anion-exchange resins exhibited the decomposition of not only free chlorine but also chloramines in water.
\end{abstract}

(Received November 26, 2009; Accepted January 15, 2010; Published March 10, 2010)

\section{Introduction}

Chlorine has been used for purification of water, in disinfectants, and in bleach. Regardless of the type of chlorine added, it exists in water as free chlorine, which is defined as dissolved gas $\mathrm{Cl}_{2}$, hypochlorous acid $\mathrm{HOCl}$, and/or hypochlorite anion $\mathrm{OCl}^{-}$. The three forms of free chlorine exist together in the equilibria: ${ }^{1-3}$

$$
\mathrm{Cl}_{2}+\mathrm{H}_{2} \mathrm{O} \rightleftharpoons \mathrm{HOCl}+\mathrm{HCl}
$$

and

$$
\mathrm{HOCl} \rightleftharpoons \mathrm{H}^{+}+\mathrm{OCl}^{-} \text {. }
$$

At the normal $\mathrm{pH}$ of tap water $(\mathrm{pH} 5.8-8.6)$, the predominant species are $\mathrm{HOCl}$ and $\mathrm{OCl}^{-}$. The free chlorine reacts with ammonia or organic amines, which can be found in natural or polluted waters, to produce chloramines (also known as combined chlorines). ${ }^{1-3}$ For example, $\mathrm{HOCl}$ reacts with $\mathrm{NH}_{3}$ to produce mono-, di-, and trichloramine species:

$$
\begin{aligned}
& \mathrm{HOCl}+\mathrm{NH}_{3} \rightleftharpoons \mathrm{NH}_{2} \mathrm{Cl}+\mathrm{H}_{2} \mathrm{O}, \\
& \mathrm{HOCl}+\mathrm{NH}_{2} \mathrm{Cl} \rightleftharpoons \mathrm{NHCl}_{2}+\mathrm{H}_{2} \mathrm{O},
\end{aligned}
$$

and

$$
\mathrm{HOCl}+\mathrm{NHCl}_{2} \rightleftharpoons \mathrm{NCl}_{3}+\mathrm{H}_{2} \mathrm{O} \text {. }
$$

The concentration of free chlorine $\left(c_{\mathrm{Cl}}\right)$ can be determined by

$\dagger$ To whom correspondence should be addressed.

E-mail: hajime@fpu.ac.jp the amperometry with a rotating Pt-disk electrode. ${ }^{4}$ The amperometric current is proportional to $c_{\mathrm{Cl}}$ without interference from chloramines, so that the electrochemical method can be applied to follow the $c_{\mathrm{Cl}}$ in the reaction mixture of free chlorine and ammonium or amine compounds more advantageously than the conventional spectrophotometric determination with chromogenic reagents. ${ }^{5,6}$ In this study, the reactions of free chlorine with different ammonium compounds in aqueous solution were investigated.

By addition of mono- and dibutylammonium $\left(\mathrm{BuNH}_{3}{ }^{+}\right.$and $\mathrm{Bu}_{2} \mathrm{NH}_{2}{ }^{+}$) species to a test solution containing free chlorine, a step-like decrease in $c_{\mathrm{Cl}}$ was observed. The decrease in $c_{\mathrm{Cl}}$ can be attributed to the formation of chloramine species. On the other hand, by addition of tributylammonium $\left(\mathrm{Bu}_{3} \mathrm{NH}^{+}\right)$species, $c_{\mathrm{Cl}}$ was decreased exponentially to nearly zero even if the free chlorine was present initially in excess. The $c_{\mathrm{Cl}}-t$ curves can be explained by $\mathrm{Bu}_{3} \mathrm{NH}^{+}$-species-catalyzed decomposition of free chlorine to $\mathrm{Cl}^{-}$ion. Other tertiary ammonium or amine species also showed the catalytic effect.

In wastewater treatment, free chlorine has usually been neutralized by the reduction with thiosulfate and sulfite compounds. ${ }^{7}$ Also, activated carbon can reduce free chlorine to $\mathrm{Cl}^{-}$ion. ${ }^{8,9}$ The catalytic decomposition by tertiary ammonium or amine species seems available to the neutralization of free chlorine advantageously. Thus the study has been extended to the reaction of free chlorine with tertiary-ammonium-based anion-exchange resins as heterogeneous catalyst. Interestingly, the polymer resins have exhibited the decomposition not only of free chlorine but also of chloramines.

\section{Experimental}

The amperometric and voltammetric experiments were 


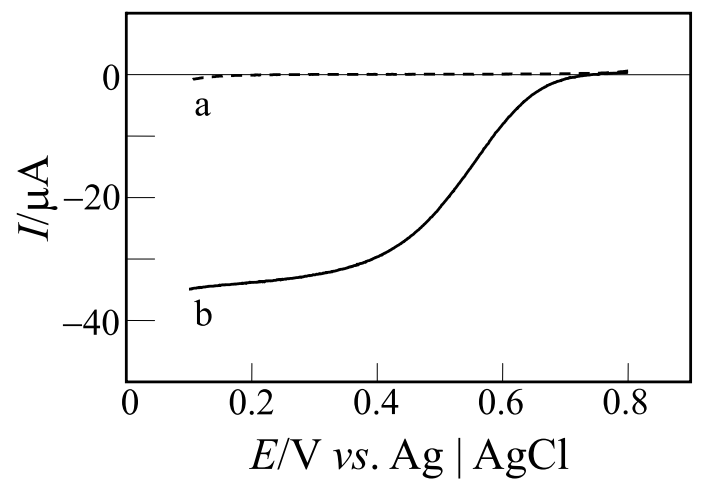

Fig. 1 Current vs. potential curves of the $0.05 \mathrm{M} \mathrm{KH}_{2} \mathrm{PO}_{4}-\mathrm{K}_{2} \mathrm{H}_{2} \mathrm{PO}_{4}$ buffer $\left(\mathrm{pH} 6.9,25^{\circ} \mathrm{C}\right)$ in the (a) absence and (b) presence of $0.5 \mathrm{mM}$ free chlorine with the rotating Pt-disk electrode at $N=1000 \mathrm{rpm}$.

performed using a three-electrode system. A platinum disk electrode (BAS 002067) was used as the working electrode. The working electrode was rotated by a rotator (BAS RDE-2). A platinum coil and an $\mathrm{Ag} \mid \mathrm{AgCl}(0.1 \mathrm{M} \mathrm{KCl})$ electrode were used as the counter electrode and the reference electrode, respectively. The body of the reference electrode was made from a glass tube (BAS 002243), to which a liquid conjunction tip of Vycor porous glass was attached. A special piece of glassware (BAS 010038) was used for the cell vial. The current $v s$. applied potential $(I-E)$ curves and the current $v s$. time curves, that is, the $c_{\mathrm{Cl}-}-t$ curves, were recorded with a laboratory-made electrochemical analyzer.

The concentration of $\mathrm{NaOCl}$ in a sodium hypochlorite solution (Nacalai Tesque) was determined by spectrophotometry with diethyl- $p$-phenylenediamine (DPD) ${ }^{5,6} \quad$ Then, the $\mathrm{NaOCl}$ solution was diluted to $50 \mathrm{mM}$. The $50 \mathrm{mM} \mathrm{NaOCl}$ solution was prepared freshly every day, and was used as the free chlorine standard solution. Solutions containing $10 \mathrm{mM}$ mono-, di-, and tributylamine and $10 \mathrm{mM} \mathrm{HCl}$ were prepared, and were used as the $10 \mathrm{mM} \mathrm{BuNH}{ }_{3}^{+}, \mathrm{Bu}_{2} \mathrm{NH}_{2}{ }^{+}$, and $\mathrm{Bu}_{3} \mathrm{NH}^{+}$standard solutions, respectively. Similarly, the standard solutions of triethanolammonium $\left(\left(\mathrm{HOC}_{2} \mathrm{H}_{4}\right)_{3} \mathrm{NH}^{+}\right)$, diethanolmethylammonium $\left(\mathrm{Me}\left(\mathrm{HOC}_{2} \mathrm{H}_{4}\right)_{2} \mathrm{NH}^{+}\right)$, trimethylammonium $\left(\mathrm{Me}_{3} \mathrm{NH}^{+}\right)$, triethylammonium $\left(\mathrm{Et}_{3} \mathrm{NH}^{+}\right)$, and tripropylammonium $\left(\mathrm{Pr}_{3} \mathrm{NH}^{+}\right)$solutions were prepared with triethanolamine, methyldiethanolamine, trimethylamine, triethylamine, and tripropylamine, respectively. Anion-exchange resins Amberlite IRA96SB and IRA67 (Organo Corp.), and Diaion WA30 (Mitsubishi Chemical Corp.) which have dimethylamino group as functional group were used as heterogeneous catalysts. The resins were pretreated with basic solution, and were used as the free base form. The test solution was buffered at $\mathrm{pH} 6.9$ with $0.05 \mathrm{M} \mathrm{KH}_{2} \mathrm{PO}_{4}-\mathrm{K}_{2} \mathrm{HPO}_{4}$, and was kept at $25 \pm 1{ }^{\circ} \mathrm{C}$ unless otherwise stated.

\section{Results and Discussion}

\section{Amperometry of free chlorine}

Curve a in Fig. 1 shows the $I-E$ curve of the $0.05 \mathrm{M}$ $\mathrm{KH}_{2} \mathrm{PO}_{4}-\mathrm{K}_{2} \mathrm{H}_{2} \mathrm{PO}_{4}\left(\mathrm{pH} 6.9,25^{\circ} \mathrm{C}\right)$ with the rotating Pt-disk electrode at the rotation rate $(N)$ of $1000 \mathrm{rpm}$. The $I-E$ curve was recorded by the linear potential sweep technique at the rate of $0.01 \mathrm{~V} \mathrm{~s}^{-1}$. Curve $\mathrm{b}$ shows the $I-E$ curve obtained by addition of $0.5 \mathrm{mM}$ free chlorine to the test solution. A well-defined cathodic wave, that is, an S-shaped $I-E$ curve with a limiting

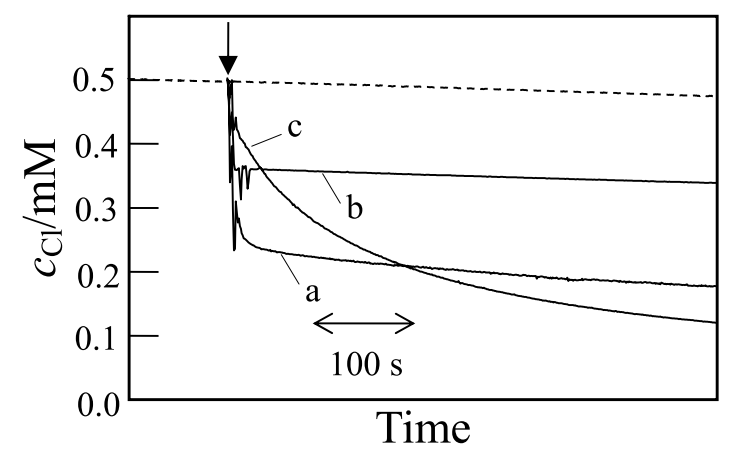

Fig. 2 Time dependence of $c_{\mathrm{Cl}}$ for the solution $\left(\mathrm{pH} 6.9,25^{\circ} \mathrm{C}\right.$ ) of $c_{\mathrm{Cl} \text {,init }}=0.5 \mathrm{mM}$ without (dashed line) and with (solid line) addition of $0.10 \mathrm{mM}$ (a) $\mathrm{BuNH}_{3}^{+}$, (b) $\mathrm{Bu}_{2} \mathrm{NH}_{2}^{+}$, and (c) $\mathrm{Bu}_{3} \mathrm{NH}^{+}$at the point indicated by the arrow.

current, is exhibited. The limiting current at $E=0.2 \mathrm{~V}$ was proportional to $c_{\mathrm{Cl}}$ and $N^{1 / 2}$, indicating that the limiting current was controlled by the diffusion of free chlorine species in the aqueous solution.

The limiting current was almost independent of $\mathrm{pH}$ in the range from 4.5 to 7.5 . The half-wave potential was shifted to positive potentials with decreasing $\mathrm{pH}$. The voltammetric current can be attributed to the reduction of free chlorine at the Pt electrode as given by ${ }^{10-12}$

$$
\mathrm{HOCl}+2 \mathrm{e}^{-} \longrightarrow \mathrm{Cl}^{-}+\mathrm{OH}^{-},
$$

with the protonation equilibrium of Eq. (2).

By addition of $1 \mathrm{mM} \mathrm{NH}_{4} \mathrm{Cl}$ to the test solution containing $0.5 \mathrm{mM}$ free chlorine, the cathodic wave of Fig. 1b disappeared within the potential range. The reaction of free chlorine with ammonia or ammonium ion is not simple, and the products vary with conditions such as $\mathrm{pH}$ and ratio of free chlorine to ammonium ion. ${ }^{1-3}$ However, it has been reported that $\mathrm{NH}_{2} \mathrm{Cl}$ is formed predominantly when the ammonium ion is present in excess of free chlorine at near neutral $\mathrm{pH} .^{3}$ The back reaction in Eq. (3) has been reported to be considerable slow (the rate constant has been reported to be $\left.3 \times 10^{-5} \mathrm{~s}^{-1}\right) .^{2}$ Therefore the experimental result indicates that the chloramine itself is electrochemically inactive and does not give kinetic current due to regenerating $\mathrm{HOCl}$. Thus the amperometric method can be applied to follow the concentration of free chlorine $c_{\mathrm{Cl}}$ even in the presence of chloramine species. In the following, $c_{\mathrm{Cl}} t$ curves can be obtained by recording the amperometric current at $E=0.2 \mathrm{~V}$.

Reactions of free chlorine with mono-, di-, and tetrabutylammonium ions

The dashed line in Fig. 2 shows the $c_{\mathrm{Cl}} t$ curve of the $0.5 \mathrm{mM}$

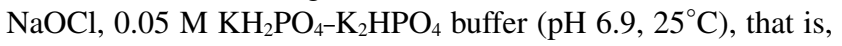
the $c_{\mathrm{Cl}} t$ curve of $c_{\mathrm{Cl}, \text { init }}=0.5 \mathrm{mM} \quad\left(c_{\mathrm{Cl}, \text { init }}\right.$ being the initial concentration of free chlorine) without addition of the ammonium salts. The $c_{\mathrm{Cl}}$ decreased slightly with time. This may be due to a spontaneous decomposition or to volatilization of free chlorine. ${ }^{13}$

Curve a in Fig. 2 shows the $c_{\mathrm{Cl}}-t$ curve of the test solution by addition of $0.10 \mathrm{mM} \mathrm{BuNH}_{3}{ }^{+}$at the point indicated by the arrow (in the following, the time is taken as $t=0$ ). By addition of $\mathrm{BuNH}_{3}{ }^{+}, c_{\mathrm{Cl}}$ decreased rapidly, and then decreased as slight as the dashed line in the figure. The step-like decrease in $c_{\mathrm{Cl}}$ may be ascribed to the formation of chlorinated monobutylammonium 


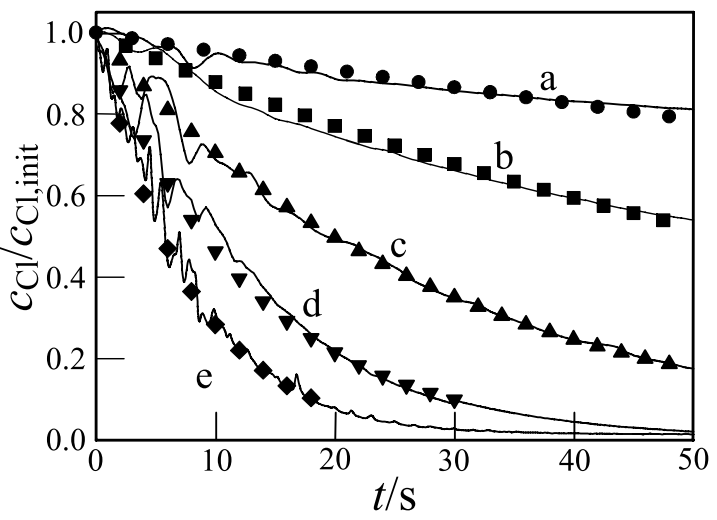

Fig. 3 Experimental $c_{\mathrm{Cl}^{-}} t$ curves for the addition of (a) 0.020, (b) 0.050 , (c) 0.10 , (d) 0.20 , and (e) $0.40 \mathrm{mM} \mathrm{Bu}_{3} \mathrm{NH}^{+}$in the test solution (pH 6.9, $25^{\circ} \mathrm{C}$ ) of $c_{\mathrm{Cl}, \text { init }}=0.2 \mathrm{mM}$ and the $c_{\mathrm{Cl}}$-values calculated by Eq. (9) with $k_{\text {app }}=0.005(\bullet), 0.013(\boldsymbol{\square}), 0.035(\mathbf{\bullet}), 0.077(\boldsymbol{\nabla})$, and $0.126(\diamond) \mathrm{s}^{-1}$.

species. The decrease in $c_{\mathrm{Cl}}$ was $c a .0 .28 \mathrm{mM}$ at $t=240 \mathrm{~s}$, suggesting that a butyltrichloramine species. The step-like decrease in $c_{\mathrm{Cl}}$ was observed also by the addition of $\mathrm{Bu}_{2} \mathrm{NH}_{2}{ }^{+}$as shown by curve b in Fig. 2. The decrease in $c_{\mathrm{Cl}}$ was $0.14 \mathrm{mM}$, suggesting the formation of dibutylchloramine and dibutyldichloramine species. We also recorded the $c_{\mathrm{Cl}}-t$ curve by addition of $0.10 \mathrm{mM}$ tetrabutylammonium chloride to the test solution of $c_{\mathrm{Cl} \text {,init }}=0.5 \mathrm{mM}$. The $c_{\mathrm{Cl}} t$ curve was almost the same as the dashed line in Fig. 2, indicating that the quaternary ammonium ion do not react with chlorine.

\section{Reaction of free chlorine with tributylammonium ion}

Curve $\mathrm{c}$ in Fig. 2 shows the $c_{\mathrm{Cl}} t$ curve obtained by addition of $0.10 \mathrm{mM} \mathrm{Bu}_{3} \mathrm{NH}^{+}$to the test solution of $c_{\mathrm{Cl}, \text { init }}=0.5 \mathrm{mM}$. The $c_{\mathrm{Cl}}$ appears to decrease exponentially. The decrease in $c_{\mathrm{Cl}}$ exceeds the initial concentration of $\mathrm{Bu}_{3} \mathrm{NH}^{+}\left(c_{\mathrm{Bu} 3 \mathrm{~N} \text {,init }}\right)$, and the $c_{\mathrm{Cl}}$ reached nearly zero when $t>500 \mathrm{~s}$. Using DPD method with $\mathrm{KI},{ }^{14}$ a chloramine species was detected in the reaction mixture when $t=60-240 \mathrm{~s}$, but it was no longer detected when $t>500 \mathrm{~s}$. We assume that $\mathrm{Bu}_{3} \mathrm{NH}^{+}$species reacts with free chlorine, e.g. $\mathrm{HOCl}$, to form a tributylchloramine species $\mathrm{Bu}_{3} \mathrm{NCl}^{+}$as intermediate by

$$
\mathrm{HOCl}+\mathrm{Bu}_{3} \mathrm{NH}^{+} \longrightarrow \mathrm{Bu}_{3} \mathrm{NCl}^{+}+\mathrm{H}_{2} \mathrm{O}
$$

and the $\mathrm{Bu}_{3} \mathrm{NCl}^{+}$decomposes to produce $\mathrm{Bu}_{3} \mathrm{NH}^{+}$species and chloride anion $\mathrm{Cl}^{-}$by

$$
\mathrm{Bu}_{3} \mathrm{NCl}^{+}+\mathrm{H}_{2} \mathrm{O} \longrightarrow \mathrm{Bu}_{3} \mathrm{NH}^{+}+\mathrm{HCl}+(1 / 2) \mathrm{O}_{2}
$$

If the decomposition of Eq. (8) is so fast that the concentration of free $\mathrm{Bu}_{3} \mathrm{NH}^{+}$can be assumed to be equated to $c_{\mathrm{Bu} \text { N, init }}$ during the reaction proceeds, the rate-determining step Eq. (7) can be approximated to the first-order with respect to free chlorine. Under such assumptions, the $c_{\mathrm{Cl}} t$ curve is given by

$$
c_{\mathrm{Cl}}=c_{\mathrm{Cl}, \text { init }} \exp \left[-k_{\mathrm{app}} t\right]
$$

where $k_{\text {app }}$ is the apparent first-order rate constant. However, Eq. (9) could not be fitted to the experimental $c_{\mathrm{Cl}^{-}} t$ curve of Fig. $2 \mathrm{c}$ in the range of $0<c_{\mathrm{Cl}} / c_{\mathrm{Cl} \text {,init }}<1$, indicating that the decomposition of Eq. (8) is not so fast.

However, the experimental $c_{\mathrm{Cl}}-t$ curves obeyed the pseudo

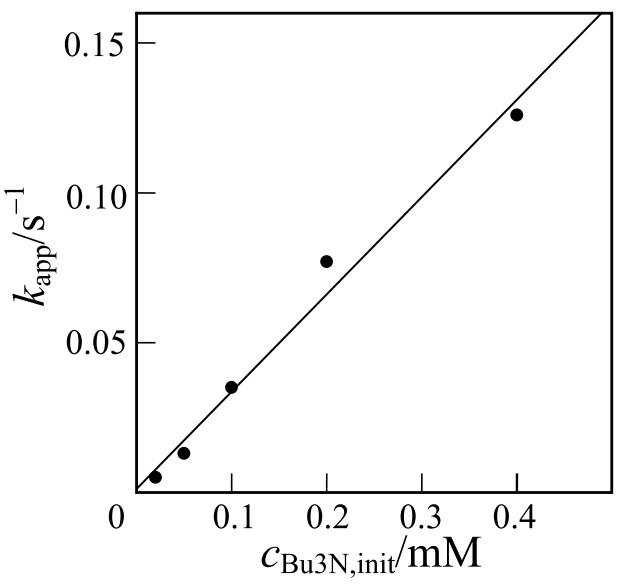

Fig. 4 Plot of $k_{\text {app }} v s . c_{\text {Bu3N,init }}$ for the test solution $\left(\mathrm{pH} 6.9,25^{\circ} \mathrm{C}\right)$ of $c_{\mathrm{Cl}, \text { init }}=0.2 \mathrm{mM}$.

first-order kinetics at certain conditions described below. Figure 3 shows the $c_{\mathrm{Cl}} t$ curves obtained by addition of $\mathrm{Bu}_{3} \mathrm{NH}^{+}$ at different concentrations to the test solution of $c_{\mathrm{Cl}, \text { init }}=0.2 \mathrm{mM}$. In the figure, the ordinate is normalized by $c_{\mathrm{Cl}, \text { init }}$. When $c_{\text {Bu3N,init }}=0.10,0.20$, and $0.40 \mathrm{mM}$ and $c_{\mathrm{Cl}, \text { init }}=0.2 \mathrm{mM}$, Eq. (9) can be fitted to the $c_{\mathrm{Cl}-} t$ curve in the range of $0.1<c_{\mathrm{Cl}} / c_{\mathrm{Cl}, \text { init }}<1$ to obtain $k_{\text {app }}=0.035,0.077$, and $0.126 \mathrm{~s}^{-1}$, respectively. When $c_{\text {Bu3N,init }}=0.020$ and $0.050 \mathrm{mM}$ and $c_{\mathrm{Cl}, \text { init }}=0.2 \mathrm{mM}$, Eq. (9) can be fitted to the $c_{\mathrm{Cl}}-t$ curve in the range of $0.8<c_{\mathrm{Cl}} / c_{\mathrm{Cl} \text {,init }}<1$ and $0.6<c_{\mathrm{Cl}} / c_{\mathrm{Cl} \text {,init }}<1$ to obtain $k_{\text {app }}=0.005$ and $0.013 \mathrm{~s}^{-1}$, respectively. The calculated $c_{\mathrm{Cl}} / c_{\mathrm{Cl}, \text { init }}$-values by Eq. (9) with the $k_{\text {app }}$-values are plotted also in Fig. 3 . The $k_{\text {app }}$-values are plotted against $c_{\mathrm{Bu} 3 \mathrm{~N} \text {,init }}$ in Fig. 4 . The regression line is given by

$$
k_{\mathrm{app}} / \mathrm{s}^{-1}=\left(0.3_{2} \pm 0.1\right)\left(c_{\mathrm{Bu3N}, \text { init }} / \mathrm{mM}\right)+\left(0.00_{1} \pm 0.02\right),
$$

indicating that $k_{\text {app }}$ is proportional to $c_{\mathrm{Bu3N}, \text { nit }}$. Also, the $c_{\mathrm{Cl}}-t$ curves recorded when $c_{\mathrm{Bu} 3 \mathrm{~N} \text {,init }}=0.20 \mathrm{mM}$ and $c_{\mathrm{Cl} \text {,init }}=0.050$ and $0.10 \mathrm{mM}$ to obtain $k_{\text {app }}=0.08 \pm 0.02$ and $0.075 \pm 0.02 \mathrm{~s}^{-1}$, respectively. The values are in agreement with $k_{\text {app }}=0.077 \mathrm{~s}^{-1}$ when $c_{\text {Bu3N,init }}=0.20 \mathrm{mM}$ and $c_{\mathrm{Cl} \text {,init }}=0.2 \mathrm{mM}$.

As shown in Fig. 5, $k_{\text {app }}$ was increased with $\mathrm{pH}$, suggesting that the reaction of Eq. (7) consists of the acid dissociation equilibrium of $\mathrm{Bu}_{3} \mathrm{NH}^{+}$:

$$
\mathrm{Bu}_{3} \mathrm{NH}^{+} \rightleftharpoons \mathrm{Bu}_{3} \mathrm{~N}+\mathrm{H}^{+},
$$

and the reaction of $\mathrm{Bu}_{3} \mathrm{~N}$ with $\mathrm{HOCl}$ :

$$
\mathrm{HOCl}+\mathrm{Bu}_{3} \mathrm{~N} \longrightarrow \mathrm{Bu}_{3} \mathrm{NCl}^{+}+\mathrm{OH}^{-}
$$

The time-dependence of the concentration of $\mathrm{Bu}_{3} \mathrm{NH}^{+}$and $\mathrm{Cl}^{-}$ ion in the reaction mixture has not been measured successfully. However, by combination of Eqs. (7) and (8), the whole reaction is given as

$$
\mathrm{HOCl} \longrightarrow \mathrm{HCl}+(1 / 2) \mathrm{O}_{2} .
$$

Thus Eq. (8) as well as Eq. (11) may be verified by the decrease of $\mathrm{pH}$ of the reaction mixture in the absence of buffer components. In the experiment, heterogeneous catalyst, e.g. tertiary-ammonium-based anion-exchange resin, can be applied advantageously because the ammonium and amine species, that is, the buffer components are not solved in the test solution. 


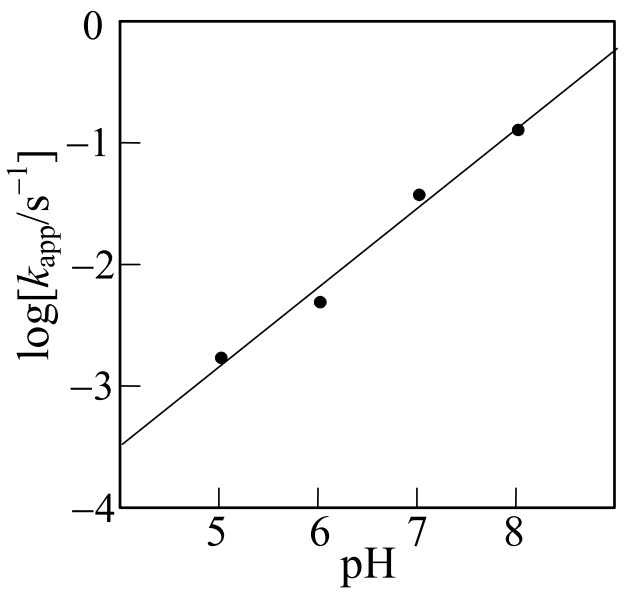

Fig. 5 Plot of $\log \left[k_{\text {app }}\right] v s$. $\mathrm{pH}$ for the test solution $\left(25^{\circ} \mathrm{C}\right)$ of $c_{\text {Bu3N,init }}=$ $0.10 \mathrm{mM}$ and $c_{\mathrm{Cl} \text {,init }}=0.2 \mathrm{mM}$.

A 250-mg of IRA96SB (free base form) and a 50-ml of $50 \mathrm{mM}$ $\mathrm{NaOCl}$ solution $(\mathrm{pH} \sim 11)$ were added in a sealed vessel. The mixture was stirred overnight so that the conversion of $\mathrm{NaOCl}$ to $\mathrm{NaCl}$ took place completely. Then the mixture was filtered off. The $\mathrm{pH}$ of the reaction mixture was lowered to $7-9$.

\section{Other tertiary ammonium/amine}

The $c_{\mathrm{Cl}}-t$ curves were recorded by addition of $0.10 \mathrm{mM}$ $\left(\mathrm{HOC}_{2} \mathrm{H}_{4}\right)_{3} \mathrm{NH}^{+}, \mathrm{Me}\left(\mathrm{HOC}_{2} \mathrm{H}_{4}\right)_{2} \mathrm{NH}^{+}, \mathrm{Me}_{3} \mathrm{NH}^{+}, \mathrm{Et}_{3} \mathrm{NH}^{+}$, and $\mathrm{Pr}_{3} \mathrm{NH}^{+}$to the test solution $\left(\mathrm{pH} 6.9,25^{\circ} \mathrm{C}\right)$ of $c_{\mathrm{Cl} \text {,init }}=0.2 \mathrm{mM}$. The $c_{\mathrm{Cl}}$ was decreased exponentially in a similar manner to that obtained by addition of $\mathrm{Bu}_{3} \mathrm{NH}^{+}$, suggesting that other tertiary ammonium or amine catalyze the decomposition of free chlorine. The $k_{\text {app }}$-value increased in order of $\left(\mathrm{HOC}_{2} \mathrm{H}_{4}\right)_{3} \mathrm{NH}^{+}<$ $\mathrm{Me}\left(\mathrm{HOC}_{2} \mathrm{H}_{4}\right)_{2} \mathrm{NH}^{+}<\mathrm{Bu}_{3} \mathrm{NH}^{+}<\mathrm{Me}_{3} \mathrm{NH}^{+}$, which corresponds to the order of the acid dissociation constant $\mathrm{p} K_{\mathrm{a}}$ of the ammonium species in aqueous solution: $\left(\mathrm{HOC}_{2} \mathrm{H}_{4}\right)_{3} \mathrm{NH}^{+}<\mathrm{Me}\left(\mathrm{HOC}_{2} \mathrm{H}_{4}\right)_{2} \mathrm{NH}^{+}$ $\left.<\mathrm{Me}_{3} \mathrm{NH}^{+} \approx \mathrm{Bu}_{3} \mathrm{NH}^{+}\right),{ }^{15}$ suggesting that the tertiary amine of higher basicity has the more effective catalytic activity.

The $\mathrm{p} K_{\mathrm{a}}$ values of the conjugate acid of mono- and dimethylchroramines $\left(\mathrm{CH}_{3}\right)_{2} \mathrm{NCl}$ and $\left(\mathrm{C}_{2} \mathrm{H}_{5}\right)_{2} \mathrm{NCl}$ are reported to be $\mathrm{p} K_{\mathrm{a}}=0.46$ and 1.0, respectively. ${ }^{15}$ The much lower $\mathrm{p} K_{\mathrm{a}}$-values suggest that the cationic form of the chloramines is not stable in aqueous media. Since the chloramine of tertiary amine exists only in the cationic form, $\mathrm{Cl}(+\mathrm{I})$ in the cationic chloramine may be converted to $\mathrm{Cl}^{-}$according to Eq. (8).

\section{Tertiary-ammonium-based anion-exchange resin}

Figure 6 shows the $c_{\mathrm{Cl}} t$ curves for the addition of $50 \mathrm{mg}$ of IRA96SB in $10 \mathrm{ml}$ of $0.2 \mathrm{mM} \mathrm{NaOCl}, 0.05 \mathrm{M} \mathrm{KH}_{2} \mathrm{PO}_{4}-\mathrm{K}_{2} \mathrm{HPO}_{4}$ buffer $\left(\mathrm{pH} 6.9,25^{\circ} \mathrm{C}\right)$. The Pt disk electrode was rotated at $N=$ $2000 \mathrm{rpm}$ to stir the resin beads. In the range of the amount of IRA96SB from 10 to $100 \mathrm{mg}$, the $c_{\mathrm{Cl}} t$ curves can be fitted to Eq. (9) in the range of $0.1<c_{\mathrm{Cl}}<1$. The obtained $k_{\text {app }}$-values were proportional to the amount of IRA96SB. Similar results were obtained with other tertiary-ammonium-based anion-exchange resins such as Amberlite IRA67 and Diaion WA30, which have dimethylamino group, and Amberlite IRC748, which has iminodiacetate group. For a comparison, the $c_{\mathrm{Cl}}-t$ curves for the addition of $50 \mathrm{mg}$ Amberlite IRA400J, which is a quaternary-ammonium-based anion-exchange resin, was recorded. As shown by curve b in Fig. 6, the decrease in $c_{\mathrm{Cl}}$ was not so fast.

The total exchange capacity of IRA96SB has been reported to

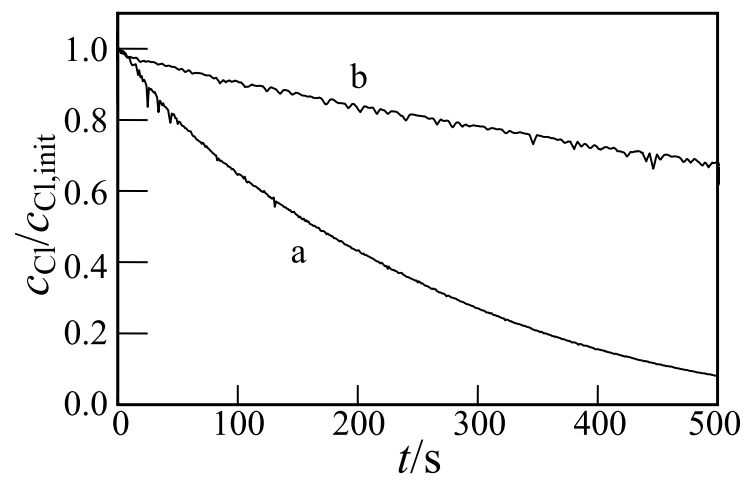

Fig. 6 Time dependence of $c_{\mathrm{Cl}}$ for the addition of $50 \mathrm{mg}$ (a)

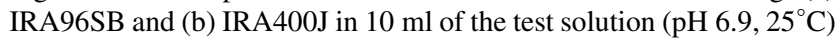
of $c_{\mathrm{Cl}, \text { init }}=0.2 \mathrm{mM}$.

be 1.25 equimole $1^{-1}$ by the supplier. If the density is assumed to be $1 \mathrm{~g} \mathrm{~cm}^{-3}, 50 \mathrm{mg}$ of IR96SB contains $\mathrm{ca}$. $60 \mu \mathrm{mol}$ of $\mathrm{Me}_{2} \mathrm{~N}$-group. The $100 \mu \mathrm{l}$ of $50 \mathrm{mM} \mathrm{NaOCl}(5 \mu \mathrm{mol})$ was added 25 times at a 1200 -s interval to $10 \mathrm{ml}$ of $0.5 \mathrm{M} \mathrm{KH}_{2} \mathrm{PO}_{4}-\mathrm{K}_{2} \mathrm{HPO}_{4}$ $\left(\mathrm{pH} 6.9,25^{\circ} \mathrm{C}\right)$ in which $50 \mathrm{mg}$ of IRA96SB was stirred, and the $c_{\mathrm{Cl}} t$ curves were recorded each time. The $k_{\text {app }}$-value tended to decrease slightly each time, indicating again that the decomposition of Eq. (8) is not so fast. However, even after the reaction with $125 \mu \mathrm{mol}$ chlorine in total, the $50 \mathrm{mg}$ of IR96SB resin exhibited the catalytic effect.

Thus polymer resins comprising tertiary amine can be applied as a heterogeneous catalyst for decomposition of free chlorine of Eq. (11). A 80-ml portion of IRA96SB resin beads was packed in a glass tube of $30 \mathrm{~mm}$ diameter to prepare a column reactor. The sample solution $\left(\mathrm{pH} 6.9,25^{\circ} \mathrm{C}\right)$ containing $4 \mathrm{mg} \mathrm{l}^{-1}$ (as $\mathrm{Cl}$ ) free chlorine was run through the column

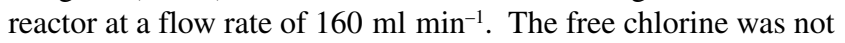
detected in the running water by DPD method, indicating that the column reactor can decompose the free chlorine completely within $30 \mathrm{~s}$.

Reaction of monochloramine with tertiary-ammonium-based anion-exchange resin

A $1 \mathrm{mM} \mathrm{NH} \mathrm{NO}_{3}$ was added to the $4 \mathrm{mg} \mathrm{l}^{-1}$ free chlorine solution ( $\mathrm{pH} 6.9,25^{\circ} \mathrm{C}$ ) to prepare the $4 \mathrm{mg} \mathrm{l}^{-1}$ ammonium chloramine solution. The concentration of the chloramines was determined by the DPD method with KI. ${ }^{14}$ The solution was run through the column at a flow rate of $160 \mathrm{ml} \mathrm{min}{ }^{-1}$. Interestingly, the concentration of the chloramines in the running water was lowered to $0.4 \mathrm{mg} \mathrm{l}^{-1}$. Chloramines produce free chlorine according to the back reaction of Eqs. (3) - (5), that is, hydrolysis. However, since the hydrolysis reactions are very slow, ${ }^{2,16}$ the decrease in the concentration of the chloramines cannot be explained by the hydrolysis preceding the catalytic reaction of Eq. (11). Probably the chloramines gave $\mathrm{Cl}(+\mathrm{I})$ directly to the $\mathrm{Me}_{2} \mathrm{~N}$-group according to

$$
\mathrm{NH}_{2} \mathrm{Cl}+\mathrm{Me}_{2} \mathrm{~N}-+\mathrm{H}^{+} \rightleftharpoons \mathrm{NH}_{3}+\mathrm{Me}_{2} \mathrm{NCl}^{+}-
$$

Thus, the electrochemical method can be applied advantageously to the study of the reactants for free chlorine. The experimental results showed that tertiary ammonium or amines catalyze the decomposition of free chlorine to chloride ion. 


\section{Acknowledgements}

This work was supported by the Grants-in-Aid (No. 21550148 to H. K.) and the Special Coordination Funds for Promoting Science and Technology (to H. T.) from the Ministry of Education, Culture, Sports, Science and Technology, the Japanese Government.

\section{References}

1. G. M. Fair, J. C. Morris, S. L. Chang, I. Weil, and R. P. Burden, J. Am. Water Works Assoc., 1948, 40, 1051.

2. V. L. Snoeyink and D. Jenkins, "Water Chemistry", 1980, John Wiley and Sons, New York, 388.

3. Pharmaceutical Society of Japan (ed.), "Eisei Shiken-hou Chukai Tsuiho (Standard Methods of Analysis for Hygienic Chemists, in Japanese)", 1990, Kanehara Shuppan, Tokyo, 946.

4. M. D. Davis and E. H. Olson, Am. J. Med. Technol., 1978, 44, 888.

5. A. T. Plain, J. Inst. Water Eng., 1967, 21, 537.
6. E. Sakurai, R. Sawamura, and A. Hamada, Eisei Kagaku (in Japanese), 1985, 31, 335.

7. C. N. Haas and M. A. Zapkin, J. Environ. Sci. Health, Part A, 1984, 19, 507.

8. M. T. Suidan, V. L. Snoeyink, and R. A. Schmitz, Environ. Sci. Technol., 1977, 11, 785.

9. T. Asada, A. Okazaki, K. Kawata, and K. Oikawa, J. Health Sci., 2009, 55, 649.

10. A. van den Berg, M. Koudelka-Hep, B. H. Van der Schoot, N. F. De Rooji, E. Verney-Norberg, and A. Grisel, Anal. Chim. Acta, 1992, 269, 75.

11. J. Jin, Y. Suzuki, N. Ishikawa, and T. Takeuchi, Anal. Sci., 2004, 20, 205.

12. F. Kodera, M. Umeda, and A. Yamada, Anal. Chim. Acta, 2005, 537, 293.

13. T. Urata, S. Tokumitsu, R. Kiyono, and M. Tasaka, J. Environ. Chem. (in Japanese), 1999, 9, 29.

14. R. Sawamura, E. Sakurai, M. Tachikawa, and A. Hasegawa, Eisei Kagaku (in Japanese), 1988, 34, 135.

15. D. D. Perrin, "Dissociation Constants of Organic Bases in Aqueous Solution", 1965, IUPAC, London, Butterworths.

16. K. Terashima and K. Ikawa, Suido-kyokai-Shi (in Japanese), $\mathbf{1 9 8 3}, 52,33$ 